Ewa Domagała-Zyśk*

ORCID: 0000-0002-2227-7102

Lublin, Poland

\title{
Integral Development of Students with Special Educational Needs in Inclusive Education from a Personalistic Perspective
}

\section{Integralny rozwój uczniów ze specjalnymi potrzebami edukacyjnymi w edukacji inkluzyjnej z perspektywy personalistycznej}

Summary: The student's right to integral development resulting from the internal dignity of each person is most fully explained in the concept of classical personalism. This right applies to every student, regardless of their age, family and social conditions or cognitive competence. In recent years, an inclusive model of education has been promoted, one promising high quality education to all students in mainstream schools. The aim of the article is to demonstrate the importance of the concept of integral upbringing based on personalism in inclusive education, being that this approach alone guarantees the authentic good of all participants of the inclusion process, without the risk of falling into collectivism or excessive individualism.

Keywords: integral upbringing; educational inclusion; special educational needs; Stefan Kunowski; personalism.

* Dr hab. prof. KUL Ewa Domagała-Zysk is a professor at The John Paul II Catholic University of Lublin, at the Institute of Pedagogy, in the Chair of Special Pedagogy. Address: Instytut Pedagogiki KUL, al. Racławickie 14, 20-950 Lublin; e-mail: ewadom@kul.pl. 
Streszczenie: Prawo ucznia do integralnego rozwoju wynika z wewnętrznej godności każdej osoby, najpełniej wyjaśnionej w koncepcji klasycznego personalizmu. To prawo dotyczy każdego ucznia, niezależnie od jego wieku, uwarunkowań rodzinnych i społecznych czy też kompetencji poznawczych. W ostatnich latach promowany jest inkluzyjny model edukacji, gwarantujący wszystkim uczniom wysokiej jakości edukację w szkołach ogólnodostępnych. Celem artykułu jest ukazanie znaczenia koncepcji integralnego wychowania w edukacji inkluzyjnej i konieczności jej oparcia na personalistycznej wizji człowieka, która gwarantuje autentyczne dobro uczestników procesu inkluzji, bez ryzyka popadnięcia w błąd kolektywizmu lub nadmiernego indywidualizmu.

Słowa kluczowe: wychowanie integralne; inkluzja edukacyjna; specjalne potrzeby edukacyjne; Stefan Kunowski; personalizm.

Positive and holistic development of students with special educational needs (SEN) is the issue in many educational institutions nowadays, having stopped being the exclusive responsibility of special educators, therapists or medical professionals. In the present era of inclusive education and inclusive practices of local communities and society in general, each person - despite his/her disability or other disorder and challenges - has a full human right to develop, learn and enjoy everyday life in his/her natural social environment, composed of family, neighbourhood, local school or institution that serves best other people of their age. In acknowledging this perspective, each teacher - be it a subject teacher, a school counsellor or a pedagogue - is responsible for the integral development of each student, also students with SEN learning in a mainstream (inclusive) school.

The aim of this paper is to analyse the principles of integral development of students with SEN and fundamentals of their inclusive education. On the one hand, this group presents exactly the same needs as other students, especially in social or emotional sphere, so general principles of integral development are to be used here. On the other hand, they have some special (specific) or additional needs that have to be recognised and answered. It is presumed that the analysis presented here might work as a framework for researchers, policymakers, teachers and other practitioners who are supposed to support the integral development of SEN students in inclusive environments. 


\section{Student's integral development in the personalistic perspective}

While searching research databases about integral development, it may be noticed that this term is used in different contexts both as a term describing an approach to a human individual development (e.g. integral early child development, integral well-being of a patient) and as a term used in reference to social groups or communities (e.g. integral leadership, integral social work, integral university). It has also started to be used in the school context as Integral Education. According to its proponents ${ }^{1}$, an integral approach in education "is not just a new set of beliefs about teaching and learning it also indicates new ways of being in the classroom and making meaning of the educational process. It is not a theory to be taught but a pointer to a naturally occurring next wave of human capacities"2.

As terms, integral development and integral education have been used for many years in Polish pedagogical research and practice ${ }^{3}$. It is indispensably connected with the conception of the identity of a human being which has been most fully described in the classical personalistic approach, which was and has been developed by such Polish authors as Bogusław F. Trentowski, Cyprian K. Norwid, Stanisław Wyspiański, Karol Wojtyła, Stefan Wyszyński, Wincenty Granat, Mieczysław Gogacz, Mieczysław A. Krapiec, Wojciech Chudy, Franciszek Adamski and many others ${ }^{4}$. The first principle of classical personalism is the conviction, that each human being is primarily a person while, only later, can we discuss his/her different characteristics. The term 'person' is much deeper than 'man' and indicates a special dignity, sovereignty and uniqueness: "Man is the only one of many entities who

1 Tom Murray, "What is integral in integral education? From progressive pedagogy to integral pedagogy", Integral Review 5/1(2009): 96-134.

2 Ibidem 127.

3 Stefan Kunowski, Podstawy wspótczesnej pedagogiki (Warszawa: Wydawnictwo Salezjańskie, 1993); Marian Nowak, Podstawy pedagogiki otwartej. Ujęcie dynamiczne w inspiracji chrześcijańskiej (Lublin: RW KUL, 2001).

${ }^{4}$ Sławmir Chrost, "Pedagogiczne implikacje humanizmu personalistycznego Wincentego Granata", Paedagogia Christiana 1/35 (2015): 181-199; Barbara Kiereś, U podstaw pedagogiki personalistycznej. Filozoficzny kontekst sporu o wychowanie (Lublin: Wydawnictwo KUL, 2015); Barbara Kiereś. "Personalizm w pedagogice", Polska Myśl Pedagogiczna 2 (2018): 271-281; Wojciech Chudy, Pedagogia godności. Elementy etyki pedagogicznej (Lublin: Towarzystwo Naukowe KUL, 2009). 
speaks about himself - 'I', opposing the whole world; he is aware of his existence and unique position - he is a person"s. Personalism has significant influence in socialisation and education and requires the teacher to treat the pupil first and foremost as a person who, although younger, physically weaker and more likely to make mistakes, nevertheless has exactly the same dignity as a strong and educated adult. As Śliwerski points out:

the personalistic view of man in the process of socialization and upbringing results in: person's affirmation as a fundamental and autotelic value, the primacy of spiritual life, irreducibility of the person to things, body, senses and biological needs, inalienability of human rights inherent in human nature, awareness of duty towards others based on the principles of justice and rejection of the anarchic concept of personal freedom ${ }^{6}$.

As a consequence, based on the principles of classical personalism, integral education might be defined as the one that

should recognise the transcendent dimension of man and his relationship also with God, without blurring the multifaceted connection of man with the world of nature. In contrast to one-dimensional biological, social, cultural or ideological approaches, it should be an approach that transcends partial and onedimensional perspectives and encompasses all spheres of human development ${ }^{7}$.

Such an understanding of education and upbringing is present in Stefan Kunowski's works (1909-1977) who clearly emphasises the necessity of comprehensive/integral human development, covering all spheres of a pupil's functioning. He is an author of the so-called layered theory of upbringing and education which describes human integral development as consisting of every of the following layers: biological, psychological, social, cultural and spiritual ${ }^{8}$. Working in the 1970s, Kunowski perceived these layers as developing one after another, but today - enriched with the psychological and pedagogical knowledge of last decades - we can treat the development of

${ }^{5}$ Mieczysław A. Krąpiec, O człowieku (Lublin: Polskie Towarzystwo Tomasza z Akwinu 2008), 14.

${ }^{6}$ Bogusław Śliwerski, Pedagogika ogólna (Kraków: Impuls, 2012), 152.

7 Nowak, Podstawy, 269.

${ }^{8}$ Kunowski, Podstawy, 197. 
these spheres as a continuous process from the child's conception until early adulthood, one leading to the formation of a mature person who is, naturally, further developing integrally throughout all his/her life.

While the development of first four layers (biological, social, cultural and ideological) seems to be well understood and described in educational literature, it is still sometimes questioned whether or not the spiritual sphere (the fifth one) should belong to the students' integral development. Kunowski defined the spiritual dimension not in terms of the categories of a certain religious system, but as the young person's ability to turn to the highest ideal of Truth, Good and Beauty. Hence, thanks to the freedom to choose a good way he/she can take responsibility for his/her own behaviour and also be responsible for other persons.

Integral human development includes integral upbringing and education. According to Kunowski, it should be understood as a multi-element process, where the following aspects should be recognised as important: 1. teachers and educators' conscious activities, 2 . external circumstances named as educational situations, 3 result of all these efforts and circumstances and 4. changes in the process of upbringing ${ }^{9}$. In this approach, everyday experiences play a significant role. Both positive as well as painful experiences make the individual aware of the powerlessness and contingency of a man in certain situations and, in a natural way, turns him towards the Absolute.

The five layers discussed make up the whole educational process which, however, does not take place in isolation from internal and external factors, independent of the pupil. Kunowski distinguishes four basic factors: bios, ethos, agos and fate. A healthy bios of the individual, i.e. free from genetic defects and diseases, is beneficial for upbringing. The right ethos is an environment free of conflicts, conveying the basic principles of natural law and morality. The edifying power of agos will manifest itself in the cooperation of parents, teachers, guardians and pastors to meet the developmental needs of the pupil. On the other hand, the most beneficial fate is such a set of events where the individual is not so much deprived of any difficulties, but rather receives appropriate support so that these difficulties can be overcome and thus shaped through work and effort ${ }^{10}$.

On the basis of these four elements, Kunowski formulated a definition of upbringing, which he understood as

\footnotetext{
9 Ibidem, 166.

${ }^{10}$ Ibidem.
} 
a long-term sequence of changes taking place in the process of comprehensive/integral human development, in which educators consciously participate through their activities. Various circumstances and conditions interact in the context of this process such as educational situations and the student's aspirations. The student himself strives to achieve greater and greater mental, moral and life independence as the furthest product of upbringing ${ }^{11}$.

This definition emphasises three elements: the complexity of the process of upbringing and its longevity, the necessity of awareness and responsibility among educators and the essence of the pupil's willingness to take care of his own development.

Kunowski also presents ${ }^{12}$ functions of such upbringing/education, which might answer the basic question: what should a pedagogue do in order to support the student's upbringing? The first of them is the function of sanarethat means taking care of the student's biological and psychological sphere, motivating them for new activities, supporting their vital energy and need of every child to develop. Next pedagogue's task is edocere - which is fulfilled both by presenting the child a proper and stimulating cognitive tasks and supporting their intellectual development thus helping them to discover the real Truth. Following these tasks, the pedagogue is also responsible for performing the next two functions - educere, which might be completed in supporting the student to move from the natural individualism and egoism to cooperate with others and be open towards the community and educarewhich is based on the responsibility to present and model student's ability to respect and participate in culture. The next function is initiare and it can be fulfilled by introducing the student into philosophical, theological and spiritual problems, supporting them in searching the answers about the sense of one's existence and the ultimate meaning of life. Function named as christianisare is perceived as the pedagogue's task to help the student to meet Jesus Christ as a real person and to live in Christ's spirit.

\section{Principles of inclusive education}

Inclusion in education is viewed as a powerful tool to secure good quality education for all. The crucial point in its development was the World Con-

\footnotetext{
11 Ibidem.

12 Ibidem, 195-198.
} 
ference on Special Needs Education: Access and Equality, held in Salamanca in 1994, with more than 300 participants representing 92 governments and 25 international organisations ${ }^{13}$. They agreed that inclusive education should be promoted as an approach enabling schools to serve all students: inclusive education means that schools should accommodate all children regardless of their physical, intellectual, social, emotional, linguistic and other conditions ${ }^{14}$. Educational inclusion is a multi-faceted term, but there is a common agreement to its meaning as proposed by UNESCO. According to the documents, inclusion is:

a process of addressing and responding to the diversity of needs of all children, youth and adults through increasing participation in learning, cultures and communities, and reducing and eliminating exclusion within and from education. It involves changes and modifications in content, approaches, structures and strategies, with a common vision that covers all children of the appropriate age range and a conviction that it is the responsibility of the regular system to educate all children ${ }^{15}$

The term is used mainly in educational context, but educational inclusion is perceived as a first step towards inclusive society: "Regular schools with inclusive orientation are the most effective means of combating discrimination, creating welcoming communities, building an inclusive society and achieving education for all"16. As such, inclusion in education can be considered as "a response to increasingly complex and diverse societies. It treats diversity as an asset which helps prepare individuals for life and active citizenship in increasingly complex, demanding, multi-cultural and integrated societies" $"$.

13 "The Salamanca Statement and Framework for Action on Special Needs Education" (1994); http://www.unesco.org/education/pdf/SALAMA_E.PDF [access: 30.11.2018].

14 Ibidem, par. 3.

15 UNESCO, Overcoming exclusion through inclusive approaches in education. A challenge and a vision. Conceptual paper (2003), 7; UNECSO, Policy guidelines on inclusion in education (UN Educational, Scientific and Cultural Organisation, 2009), 8-9.

16 "The Salamanca", par. 2.

17 European Agency for Special Needs and Inclusive Education, "Inclusive education for learners with disabilities. Study for the PETI Committee" (2017): 7; http://www.europarl. europa.eu/RegData/etudes/STUD/2017/596807/IPOL_STU(2017)596807_EN.pdf [access: 30.11.2018]. 
Inclusion is strongly based on principles of equality and equity. Although they sound as similar, they address two different concepts. Equality is based on the conviction of the innate value and self-worth of each human being; in the educational context, it implies the right of every person to be treated in a way that guarantees access to the same educational opportunities. Equity might be perceived as a two-dimensional construct, being that as fairness, "which implies ensuring that personal and social circumstances $[\ldots]$ should not be an obstacle to achieving educational potential, and as inclusion, which implies 'ensuring a basic minimum standard of education for all"' 18 . Equality and equity are not understood as identical and it is proclaimed that

education systems must move away from the traditional 'one-size-fits all' mentality. Equal opportunities for all are crucial, but not sufficient: there is a need to pursue 'equity' in the aims, content, teaching methods and forms of learning being provided for by education and training systems to achieve a high-quality education for all ${ }^{19}$.

As has been mentioned, inclusive education is understood as a process and, not surprisingly, it is in the continuous state of development. Nevertheless, there are some principles of inclusive education that seems to be well established and widely used. They might also be called "inclusive culture" principles and are as following:

1. School leaders should be strongly convinced that inclusion in education means good quality of education for all and perceive learners' diversity as an opportunity not as a problem; they should be committed to inclusive values and to a leadership style which encourages others to participate in leadership functions.

2. Supportive teachers are crucial levers of creating inclusive schools mainly in the context of their involvement in inclusion awareness, promotion of flexible teaching and learning methods and materials and making the best use of human resources, which should also take

18 Simon Field, Małgorzata Kuczera, Beatriz Pont, No more failures. Ten steps to equity in education (OECD, 2007), 11; https://www.oecd.org/education/school/45179151.pdf [access: 30.11.2018].

19 EU Council, "Conclusions of the Council and of the Representatives of the Governments of the Member States, meeting within the Council, on Inclusion in Diversity to achieve a High Quality Education For All”, Official Journal of the European Union 62/02 (2017/C): 4. 
place in the context of staff collaboration, joint problem-solving and peer co-operation.

3. Accessibility of physical environment, both in the context of architecture, web accessibility, teaching materials accessibility and social attitudes is a crucial element of students' involvement in the learning process.

4. Teaching/learning process should be based on flexible curriculum, accommodated and modified to answer diverse needs of the student population.

5. Educational inclusion should include families and be immersed in the local community in general; educational institutions should cooperate with different social agents (NGOs and other public and private educational and cultural institutions).

Educational practice and research on inclusion understood as a highquality education for all in Poland has just started because, so far, the dominant model of co-existence of persons with and without disability - both in schools and in society in general - was named as integration. Integration can be defined as all activities aiming at incorporating persons with special needs/disabilities into the non-disabled society ${ }^{20}$. In such an approach, two groups can be clearly perceived: the majority of these who govern a certain field and a minority who aspires to be accepted, usually only after fulfilling certain conditions. Integration is a natural and useful stage in between segregation and inclusion, but cannot be treated as an approach which can replace inclusion.

\section{Challenges and chances for integral development of students with special educational needs in inclusive settings}

Inclusion in education is a concept used in different educational systems all over the world and thus has to be adapted to different context. It is visible

${ }^{20}$ Edukacja integracyjna $i$ włączająca $w$ doświadczeniach pedagogów i nauczycieli, ed. Zdzisława Janiszewska-Nieścioruk (Kraków: Impuls, 2012); Grzegorz Szumski, Wokót edukacji włączającej. Efekty ksztatcenia uczniów z niepetnosprawnością intelektualna w stopniu lekkim w klasach specjalnych, integracyjnych i ogólnodostępnych (Warszawa: Wydawnictwo APS, 2010); Danuta Al-Khamisy, Edukacja włączajaca edukacją dialogu. W poszukiwaniu modelu edukacji dla ucznia ze specjalnymi potrzebami edukacyjnymi (Warszawa: Wydawnictwo APS, 2013). 
e.g. in a statement of European Agency for Special Needs and Inclusive Education: "All European countries are committed to working towards ensuring more inclusive education systems. They do so in different ways, depending on their past and current contexts and histories" ${ }^{21}$. It is also necessary for Poland to use its historical and social context to create a unique Polish model of inclusion in accordance with our national circumstances. Taking into account Polish pedagogical traditions and contemporary research ${ }^{22}$, it should be stressed that this model of educational inclusion can be closely linked to the ideas of student's integral development within the personalistic perspective.

First and foremost, the principles underlying integral development and inclusion are deeply humanistic and close to each other. They both stress the necessity of a student's full human development (biological, social, cultural and spiritual) which is not the sole way forward, but should be undertaken within a community: "what is important in the educational process - it exists in between human beings: relationships, bonds, communication, activities and intentions - all them constitute this process" 23 .

Inclusive approach to education is also deeply humanistic in this sense that it is about supporting these in need: "This [inclusive] community aims to support the weakest, while encouraging the strongest to achieve their best, and ensure all members feel respected, valued and enabled to fully participate in the school community"24. Such a statement can be supported with a personalistic recognition of a human being as an entity possessing full human dignity despite his or her disorders, disabilities or simply diverse characteristics ${ }^{25}$.

${ }^{21}$ European Agency for Special Needs and Inclusive Education, Agency position on inclusive education system (Odense: 2015).

${ }^{22}$ Also research on student and teacher's subjectivity, cf. Lucyna Górska (Dziaczkowska), Podmiot i podmiotowość w wychowaniu. Studium w perspektywie poznawczej pedagogiki integralnej (Szczecin: Wydawnictwo Uniwersytetu Szczecińskiego, 2008) and Lucyna Dziaczkowska, "Z dyskusji o istocie, potrzebie i granicach podmiotowości uczestników rzeczywistości wychowawczej”, Paedagogia Christiana 1/29 (2012): 31-48.

${ }^{23}$ Wojciech Chudy, "Istota pedagogiki personalistycznej”, in: Wychowanie chrześcijańskie. Miedzy tradycja a wspótczesnościa, ed. Alina Rynio (Lublin: Wydawnictwo KUL, 2007), 271-295.

${ }^{24}$ European Agency for Special Needs and Inclusive Education, Inclusive education.

${ }^{25}$ Ewa Domagała-Zyśk, „Chrześcijańska pedagogika niepełnosprawności - współczesne wyzwania", in: Pedagogika chrześcijańska. Tradycja, współczesność, nowe wyzwania, ed. Jarosław Michalski, Aldona Zakrzewska (Toruń: Wydawnictwo Adam Marszałek, 2010), 495-509. 
Inclusion is definitely about taking care of every person, despite his/ her age, competence level, achievements, temporary or permanent health or educational problems. If we take this approach, then the inclusive school environment (e.g. ramps instead of stairs, books in electronic formats which can easily be accessed or printed in different other formats, usage of varied teaching strategies) can support not only those with life-long conditions, but also students with temporary problems connected with e.g. a broken leg or allergic treatments demanding several days at home.

These practical solution are, in their very core sense, based on the personalistic, philosophical dimensions of potentiality and contingency. Each human being is potential - not completed - who has been developing his/her potentialities since conception until one's death. We differ as to the scope of these potentialities and their development, but both those with a narrow and those with wide range of achievements are perceived in personalism as equal in respect to their human dignity and right to be respected. Each human being is a contingent being, experiencing every day his/her fragility in the face of fate and nature. One who is fully healthy and strong may, a minute after a car accident, become weak and disabled. The idea of including all students in a good quality educational experience can thus be a guarantee of not leaving behind any student in any life circumstances.

When introducing inclusion in schools and other communities, it might be useful to base it on Kunowski's functions of education. These functions show the teachers and educators a framework of supporting each child and whole communities by fulfilling the tasks of acknowledging each student's right and desire to have their biological and psychological needs fulfilled (sanare), be cognitively stimulated and challenged (edocere), feel the necessity to be with others without infringing their rights or freedoms (educere) and participate in local, national and world culture of inclusion (educare). All these activities and functions have a chance to be fully meaningful in the enriching context of initiare and christianisare. Respecting such a model of education enables the confirmation of both individual rights and the well-being of school or local community.

\section{Conclusion}

Inclusion in education needs careful consideration about its anthropology. If based on personalistic viewpoint, it can bring integral development, effective education and participation for everyone - disabled and non-disabled 
students, their families, teachers and local community. However, inclusion might sometimes be wrongly understood as a kind of ideology of modern education, taking the form of inclusion at all costs just for the sake of fulfilling the utopian programmes of international policy makers, based solely on the concepts of collectivism or individualism ${ }^{26}$. For some students, institutions other than mainstream, inclusive schools might be a better place of education and learning life skills. Teachers in mainstream local schools should not only consider various needs of students with special educational needs but the needs of every student in the class. Parents have a right to know that their child - having or not having special (additional) needs - feels at school safe, cared for and taught with consideration.

Inclusive education should not be about education for all, but good quality of education for everyone, with full acknowledgment of each student's dignity, uniqueness and, at the same time, their indispensable need and right to live and learn in a supportive community. These are the true meanings of personalism, integral development and inclusion.

\section{References}

Al-Khamisy, Danuta. Edukacja właczająca edukacja dialogu. W poszukiwaniu modelu edukacji dla ucznia ze specjalnymi potrzebami edukacyjnymi. Warszawa: Wydawnictwo APS, 2013.

Chrost, Sławomir. "Pedagogiczne implikacje humanizmu personalistycznego Wincentego Granata". Paedagogia Christiana 1/35 (2015): 181-199.

Chudy, Wojciech. "Istota pedagogiki personalistycznej”. In: Wychowanie chrześcijańskie. Miedzy tradycją a wspótczesnościa, ed. Alina Rynio, 271-295. Lublin: Wydawnictwo KUL, 2007.

Chudy, Wojciech. Pedagogia godności. Elementy etyki pedagogicznej. Lublin: Towarzystwo Naukowe KUL, 2009.

Domagała-Zyśk, Ewa. "Chrześcijańska pedagogika niepełnosprawności - współczesne wyzwania". In: Pedagogika chrześcijańska. Tradycja, współczesność, nowe wyzwania, ed. Jarosław Michalski, Aldona Zakrzewska, 495-509. Toruń: Wydawnictwo Adam Marszałek, 2010.

Domagała-Zyśk, Ewa. "Projektowanie uniwersalne w edukacji osób z wadą słuchu". In: Z problematyki teatrologii i pedagogiki, ed. Marian Nowak, Elżbieta Stoch, Barbara Borowska, 553-568. Lublin: Wydawnictwo KUL, 2015.

${ }^{26}$ Kiereś, "Personalizm”, 271-281. 
Górska (Dziaczkowska), Lucyna. Podmiot i podmiotowość w wychowaniu. Studium w perspektywie poznawczej pedagogiki integralnej. Szczecin: Wydawnictwo Uniwersytetu Szczecińskiego, 2008.

Dziaczkowska, Lucyna. " $Z$ dyskusji o istocie, potrzebie i granicach podmiotowości uczestników rzeczywistości wychowawczej”. Paedagogia Christiana 1/29 (2012): 31-48.

EU Council. "Conclusions of the Council and of the Representatives of the Governments of the Member States, meeting within the Council, on Inclusion in Diversity to achieve a High Quality Education For All". Official Journal of the European Union, 62/02 (2017/C): 1-7.

Edukacja integracyjna $i$ wtaczająca $w$ doświadczeniach pedagogów i nauczycieli, ed. Zdzisława Janiszewska-Nieścioruk. Kraków: Impuls, 2012.

Kiereś, Barbara. U podstaw pedagogiki personalistycznej. Filozoficzny kontekst sporu o wychowanie. Lublin: Wydawnictwo KUL, 2015.

Kiereś, Barbara. "Personalizm w pedagogice”. Polska Myśl Pedagogiczna 2 (2018): 271-281.

Krąpiec, Mieczysław A. O człowieku. Lublin: Polskie Towarzystwo Tomasza z Akwinu, 2008.

Kunowski, Stefan. Podstawy wspótczesnej pedagogiki. Warszawa: Wydawnictwo Salezjańskie, 1993.

Murray, Tom. "What is integral in integral education? From progressive pedagogy to integral pedagogy". Integral Review 5/1(2009): 96-144.

Nowak, Marian. Podstawy pedagogiki otwartej. Ujęcie dynamiczne w inspiracji chrześcijańskiej. Lublin: RW KUL, 2001.

Szumski, Grzegorz. Wokół edukacji włączającej. Efekty kształcenia uczniów z niepetnosprawnościq intelektualna $w$ stopniu lekkim $w$ klasach specjalnych, integracyjnych i ogólnodostępnych. Warszawa: Wydawnictwo APS, 2010.

Śliwerski, Bogusław. Pedagogika ogólna. Kraków: Impuls, 2012. 
